\title{
Net energy benefits of carbon nanotube applications
}

\author{
Pei Zhai ${ }^{1,2, *}$, Jacqueline A. Isaacs ${ }^{1}$, Matthew J. Eckelman ${ }^{2}$ \\ ${ }^{1}$ Civil and Environmental Engineering, Northeastern University, Boston, MA, USA \\ ${ }^{2}$ Mechanical and Industrial Engineering, Northeastern University, Boston, MA, USA \\ *Corresponding author, email: clarezhai@gmail.com
}

\begin{abstract}
Implementation of carbon nanotubes (CNTs) in various applications can reduce material and energy requirements of products, resulting in energy savings. However, processes for the production of carbon nanotubes (CNTs) are energy-intensive and can require extensive purification. In this study, we investigate the net energy benefits of three CNT-enabled technologies: multi-walled CNT (MWCNT) reinforced cement used as highway construction material, single-walled CNT (SWCNT) flash memory switches used in cell phones and CNT anodes and cathodes used in lithium-ion batteries used in electric vehicles. We explore the avoided or additional energy requirement in the manufacturing and use phases and estimate the life cycle net energy benefits for each application. Additional scenario analysis and Monte Carlo simulation of parameter uncertainties resulted in probability distributions of net energy benefits, indicating that net energy benefits are dependent on the application with confidence intervals straddling the breakeven line in some cases. Analysis of simulation results reveals that SWCNT switch flash memory and MWCNT Li-ion battery cathodes have statistically significant positive net energy benefits ( $\alpha=0.05$ ) and SWCNT Li-ion battery anodes tend to have negative net energy benefits, while positive results for MWCNT-reinforced cement were significant only under an efficient CNT production scenario and a lower confidence level $(\alpha=0.1)$.
\end{abstract}

\section{Key words:}

Net energy analysis; Life cycle assessment; Carbon nanotube; Lithium ion battery; Uncertainty analysis; Environmental analysis 


\section{Introduction}

Carbon nanotubes (CNTs) are tube-shaped materials, made solely of carbon, with a diameter on a nanometer scale. They are structurally grouped as single-walled CNTs (SWCNTs) or multi-walled CNTs (MWCNTs) [1]. Carbon-based nanotechnologies such as CNTs and carbon nanofiber (CNF) show great promise in a variety of applications due to their excellent mechanical, electrical and thermal characteristics [2]. As additions to existing applications, CNTs are touted for improving performance in flexible electronics [3], polymer composites [4], semiconducting transistors [5], memory chips [6], and energy storage technologies [7-9]. There are several CNT-enabled products already on the market, including sporting goods [10], and specialty thermoplastics [11]. MWCNTs accounted for the majority of the CNT market volume in 2014 [12], mainly driven by applications in polymer composites and lithiumion batteries. MWCNT production is expected to reach more than 3,700 metric tons by 2020 [13], while SWCNT growth is not expected to increase as rapidly due to their higher prices.

Utilization of CNTs could bring many environmental and health benefits through enhanced product performance [14]. For example, CNTs have been employed in numerous sensor technologies to detect trace contaminants [15] and in water filtration devices to purify contaminated water [16]. Yet concerns remain regarding CNT releases and subsequent potential exposures and toxicity to humans and ecosystems [17-19], with continued reductions in recommended exposure limits [20]. The production of CNTs is material- and energy-intensive relative to other industrial products[21], and associated upstream (supply-chain) emissions can also lead to significant environmental and health impacts [22]. To understand the overall balance of burdens and benefits, it is necessary to apply a life cycle perspective.

Several life cycle assessment (LCA) studies have investigated environmental impacts of CNT-based applications. In terms of the product life cycle, previous studies can grouped into 1) cradle-to-gate analyses, which consider only the manufacturing phase, and 2) cradle-to-grave analyses, which consider both manufacturing and use phases (sometimes including the end-of-life phase). Hischier and Walser [23] reviewed LCA publications of nanotechnologies and emphasized that a proper scope (cradle-tograve) is often lacking, resulting in studies that do not capture the performance benefits of using nanomaterials in the first place. Cradle-to- grave studies can offer greater insights on the overall benefit or burden of a technology. For emerging technologies and new materials, however, the required data can be difficult to capture throughout the life cycle, particularly characterization factors required for fate, exposure, and effect (toxicity) modeling for nanomaterials.

LCA studies typically consider multiple categories of impact, but LCA can also be applied to study a single endpoint. Some researchers have used a single-metric net benefit analysis to determine whether there are overall advantages of nanomaterials over the product life cycle. As an example of a cradle-to-grave study, Khanna and Bakshi [24] reported that using CNF polymer composites to replace steel in automotive body panels could result in net energy savings except under extremely conservative assumptions. Gilbertson et al. [15] reported that using CNT-enabled chemical gas sensors could result in net health benefits if their implementation prevents a certain number of occupational casualties. 
The use of net energy analyses requires quantitative evaluation of energy utilized in each phase of the life cycle. Several studies [25-27] draw conclusions that it is energy-intensive to produce CNTs compared with conventional carbon materials. Kim and Fthenakis [28] provided a comprehensive review of energy and greenhouse gas (GHG) emission implications of nanomaterials, including carbon-based materials, and found enormous discrepancies in reported primary energy requirements for CNT production. For example, energy requirements for SWCNT production using the same method could range from 2.4 $\mathrm{GJ} / \mathrm{kg}$ [26] to $880 \mathrm{GJ} / \mathrm{kg}$ [25]. Expanded discussion of these numbers is found in a subsequent section ('Energy requirement for CNT production'). Using a net energy analysis to compare battery technologies, Wender and Seager 2011 [29] and a US EPA report [30] established that using SWCNTs to replace graphite anodes could result in a negative energy benefit (between 45 and $130 \mathrm{MWh}$ of additional electricity per kWh of battery storage capacity). However, the potential benefit during vehicle use resulting from reduced battery weight was not addressed. Most studies to date have focused on energy requirements during manufacturing; however to reap the potential benefit of CNT-enabled technologies, at least in terms of energy and GHG emissions, it is important to assess and compare the energy requirements and potential savings during the use phase as well.

To capture the potential energy trade-offs along the product life cycle, the scope of this study includes both the manufacturing and use phases, using a net energy analysis approach. Three CNT-enabled applications that have attracted broad attention from research institutes and industry are investigated including: MWCNT reinforced cement, SWCNT switches used in flash memory of cell phones, and CNT electrodes in lithium-ion (Li-ion) batteries for electric vehicles.

\section{General methodology - Net energy analysis}

The methodology used in the present study is derived from the concept of net energy analysis, which has been employed for several decades to investigate the energy efficiency of industrial processes and systems [31-34]. More recently, researchers have applied this concept to energy systems to quantify the amount of energy a technology produces during its lifetime relative to the energy required to produce it, or the energy return on energy invested, e.g., grid storage [35], solar water-splitting [36], solar and thermal storage [37], and bio-energy technologies [38-40]. A fundamental metric in net energy analysis is the primary energy requirement, which is the sum total of all raw forms of energy used; for a product life cycle assessment, this includes primary energy used from extraction of natural resources (including fuels), preparation of materials, manufacturing the product, transportation, and product use. In some publications on this topic, authors have used other terms, including 'energy consumption' [41], 'energy requirement' [26]. or 'cumulative energy demand' [42] to depict the same meaning of 'primary energy requirement'. Here, 'net energy' denotes 'net primary energy'.

For this study, when CNTs replace conventional materials in the products, the 'additional energy used' to produce CNTs must be balanced against the energy saved by avoiding the production of the replaced materials, as well as differences during the use phase. All primary energy data are taken from cumulative energy demand (CED) reported by the ecoinvent v2.2 database (CED impact assessment 
method v1.08) [43], and include fossil, nuclear, and renewable forms of primary energy. Because of the life cycle approach, cumulative energy demand values include primary energy used in fuel production and transport and embodied in equipment and infrastructure. The energy data for CNTs are adjusted from Kushnir and Sanden [26] which reported electrical energy and thermal energy separately (however they use thermal energy to represent the embodied energy of feedstock and other materials). Here we differentiate between embodied energy of non-fuel inputs and thermal energy, converting to primary energy based on the heat content of the fuel plus energy used in its production and transport. The factor of 1.12 MJ primary energy per MJ fuel is used for natural gas in North America [43]. For calculation of the primary energy of electricity, a primary energy-to-electricity (MJ/MJ) conversion factor of 0.29 is applied, derived as the inverse of the cumulative energy demand of $12.5 \mathrm{MJ} / \mathrm{kWh}$ reported by ecoinvent v2.2 database for the U.S. electricity production mix [43].

\subsection{Manufacturing phase}

The embodied energy of CNTs is accounted for as 'additional energy requirement' in the manufacturing phase. In some instances, CNTs are used to substitute for materials in conventional technologies. For example, CNTs used in Li-ion battery electrodes could substitute for current materials used in anodes, binders and current collectors [44]. The embodied energy of these replaced materials must be accounted for as 'avoided energy requirement' in the manufacturing phase, and are detailed below for each case study.

\subsection{Use phase}

CNT-enabled products could also potentially save energy in the use phase. For example, use of CNTs in automotive Li-ion batteries could reduce the weight of the battery, which results in weight reduction of a vehicle and further energy reduction during vehicle use. The energy embodied of the saved electricity is accounted for as 'avoided energy requirement' in the use phase.

\subsection{Life cycle net energy benefit}

Here, we define the term 'net energy benefit' to equal the difference between applications using CNTs and conventional materials, both in manufacturing and use phases as shown in Equation (1) and represented in Figure 1. A positive net energy benefit would indicate that a CNT-enabled product could save energy over its life cycle; while a negative net energy benefit would signify that more energy would be spent than saved.

Net energy benefit $==\left(E_{m f g}^{C N T}-E_{m f g}^{\text {conventional }}\right)+\left(E_{\text {use }}^{C N T}-E_{\text {use }}^{\text {conventional }}\right)$ 
where $E_{m f g}^{C N T}$ and $E_{u s e}^{C N T}$ depict the energy requirement of CNT applications in manufacturing and use phases, respectively, and $E_{m f g}^{\text {Conventional }}$ and $E_{\text {use }}^{\text {Conventional depict the energy requirement of }}$ conventional applications in manufacturing and use phases, respectively.

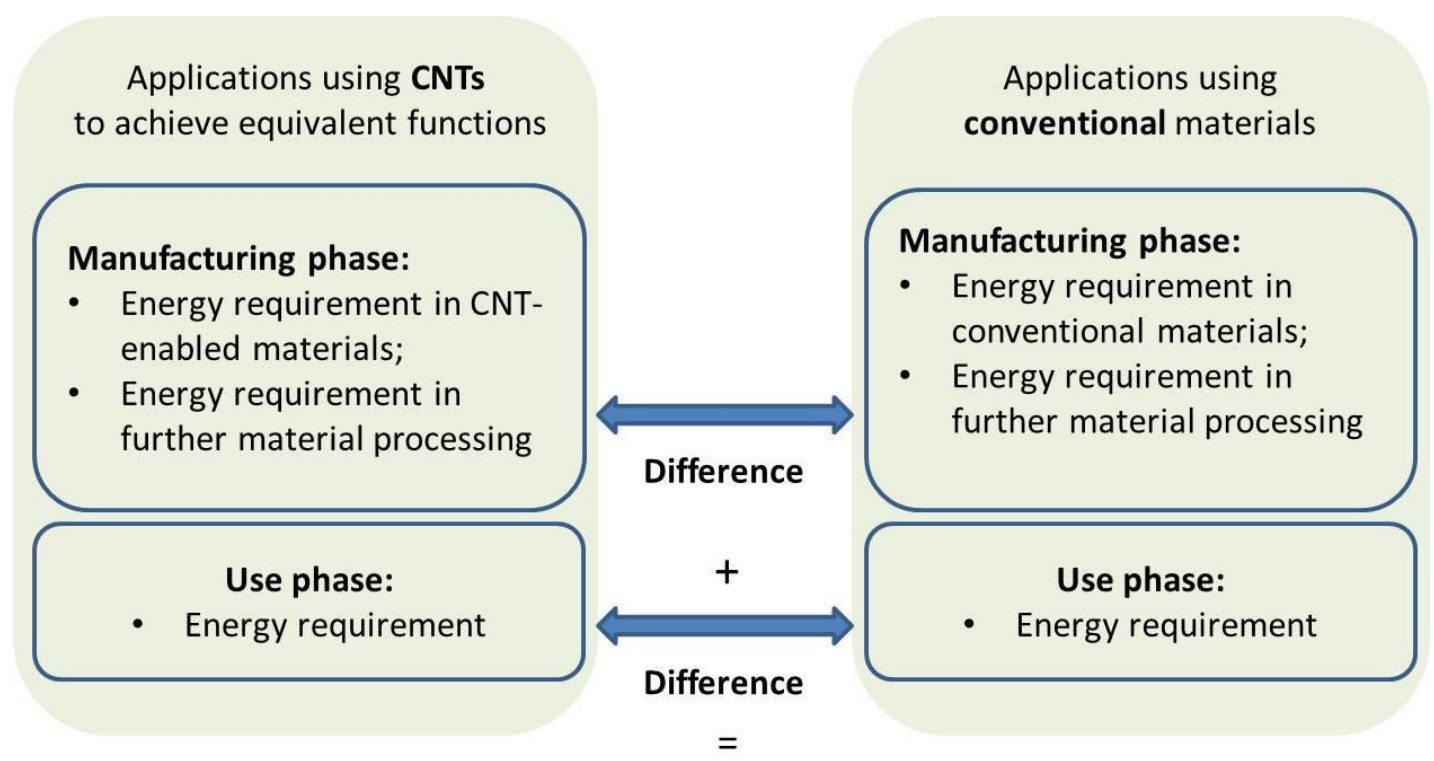

Net Energy Benefit

Figure 1: The scope of net energy benefit comparing products using CNTs and conventional materials (system boundary)

\subsection{Functional units}

The functional units for each application are listed in Table 1. The energy values are calculated as MJ per functional unit.

Table 1: Functional units of each CNT-enabled application

\begin{tabular}{|ll|}
\hline Applications & Functional units \\
\hline MWCNT reinforced cement & $1000 \mathrm{~kg}$ mass of cement \\
\hline SWCNT switch flash memory used in cell phone & $16 \mathrm{~Gb}$ capacity of memory \\
\hline SWCNT Li-ion battery anodes & $16 \mathrm{kWh}$ capacity of battery \\
\hline MWCNT Li-ion battery cathodes & $16 \mathrm{kWh}$ capacity of battery \\
\hline
\end{tabular}

\section{Energy requirements for CNT production}

There are three common synthesis techniques of SWCNTs production, [25-27], which include chemical vapor deposition (CVD), high pressure carbon monoxide (HiPco), and electric arc (or arc ablation). Comparisons of the energy requirement for each technique have been detailed in review articles [23, 28]. Both Kushnir and Sanden [26] and Healy et al. [25] investigated energy requirements for CNT production and purification. For Kushnir and Sanden [26], the catalytic CVD method was the least energy 
intensive production process; while Healy et al. [25], HiPco was the least energy intensive. A comparison of the CVD methods (including synthesis and purification) from references $[25,26]$ is listed in Table 2. CVD is a catalytic synthesis method in which hydrocarbon feedstock (methane) in an atmosphere with gases (hydrogen, nitrogen, argon), react in the presence of metal catalyst (iron and cobalt). The reaction temperature ranges from $800-1000^{\circ} \mathrm{C}$. The CVD method (fluidized bed CVD) also requires a catalyst support bed made of $\mathrm{MgO}$. The purification process involves acid wash and an electrically driven ultrasonic stirrer, resulting in $90 \%$ purity reported in both publications $[25,26]$.

The results of energy requirement in Healy et al. [25] (using empirical lab-scale data) is much higher than Kushnir and Sanden (using modeled commercial-scale results) [26]. The difference is largely due to different process assumptions associated with different production scales, particularly for yield ( $3 \%$ vs. $30 \%$, respectively) and reaction temperatures $\left(1,000^{\circ} \mathrm{C}\right.$ vs. $800^{\circ} \mathrm{C}$, respectively). CNT synthesis techniques and production scales have advanced in recent years, leading to decreases in energy requirements. Gavankar et al. reported that the energy requirement for CNT production at laboratory scale is eight times that for industrial scale production [27]. Because most manufacturers currently use catalytic CVD for CNT production [45] and commercial-scale processes are more relevant for product modeling than laboratory-scale, the energy results for CVD methods from Kushnir and Sanden [26] are assumed for this study. Although the technology and scale of CNT production have evolved in recent years, the prospective analysis of Kushnir and Sanden are not outdated, because from a methodology perspective, the model was based on future mass industrial-scale production and could be used to estimate current and near future energy requirements of CNT production [27].

Kushnir and Sanden included two scenarios for analysis: a 'baseline scenario' and an 'efficient scenario' [26]. The main difference lies in the assumption of the amount of catalyst support. In the baseline scenario, the authors employed the CVD method reported by Wang et al. [46], which assumes a product-to-catalyst ratio of 2. In the efficient scenario, the CVD method, reported by Li et al. [47], showed a product-to-catalyst ratio of 10 . Since $80 \%$ of the energy requirement consists of the embodied energy for the catalyst support and the acid used to dissolve it later, the energy requirement is much lower in the efficient scenario. However, the efficient scenario suffers from much lower reaction rates and production throughput. It should be noted that Kushnir and Sanden proposed the efficient scenario for SWCNTs production based on Li et al. [47]; however, Li et al. investigated MWCNTs production, not SWCNTs, so the proposed efficient scenario for SWCNTs may be unrealistic. Hence, the baseline scenario may be closer to the realistic situation. In addition to SWCNTs, Kushnir and Sanden [26] also reported the energy requirement for producing MWCNTs using CVD, but without a catalyst support bed. In this set of results, the largest energy input resulted from electricity use.

In the following sections, all calculations are based on the baseline scenario data. In the subsequent uncertainty analysis (Section 5), we present net energy results for both baseline and efficient scenarios. 
Table 2: Energy requirements and assumptions for CVD synthesis and purification of CNTs

\begin{tabular}{|c|c|c|c|c|c|c|c|c|}
\hline $\begin{array}{l}\text { CNT } \\
\text { Type }\end{array}$ & Scenario & $\begin{array}{l}\text { Product- } \\
\text { to-catalyst } \\
\text { ratio }\end{array}$ & Yield & Scale & $\begin{array}{l}\text { Embodied } \\
\text { energy } \\
\text { (MJ/kg) }\end{array}$ & $\begin{array}{l}\text { Electrical } \\
\text { energy } \\
(\mathrm{MJ} / \mathrm{kg})\end{array}$ & $\begin{array}{l}\text { Total } \\
\text { primary } \\
\text { energy } \\
\text { (MJ/kg) }\end{array}$ & Ref. \\
\hline \multirow{2}{*}{ SWCNTs } & Baseline & 2 & $30 \%$ & Industry & 328 & 626 & 2,490 & [26] \\
\hline & Efficient & 10 & $30 \%$ & Industry & 93 & 220 & 852 & [26] \\
\hline \multirow[t]{2}{*}{ MWCNTs } & Baseline & $\begin{array}{l}\text { No catalyst } \\
\text { support }\end{array}$ & $\begin{array}{l}\text { Un- } \\
\text { known }\end{array}$ & Industry & 295 & 187 & 940 & [26] \\
\hline & Efficient & $\begin{array}{l}\text { No catalyst } \\
\text { support }\end{array}$ & $\begin{array}{l}\text { Un- } \\
\text { known }\end{array}$ & Industry & 65 & 67 & 296 & [26] \\
\hline
\end{tabular}

\section{Net energy benefits for three case studies}

\subsection{MWCNT reinforced cement in highway construction (1000 kg cement)}

Concrete reinforcement using carbon nanomaterials is a rapidly growing research area [48]. The use of nanosize particles could prevent the transformation of nanocracks into microcracks and in turn, macrocracks [48]. CNTs have excellent mechanical properties that could strengthen cementitious composites [49]. However, CNTs tend to agglomerate in cementitious composites, making it difficult to achieve homogeneous dispersion. The use of ultrasonic mixers and surfactants assist in achieving good dispersion [48, 49]. Parveen et al. [48] published a review paper that summarized the lab-scale achievements of using MWCNTs to strengthen cementitious composites. Improvements depend on many factors, including CNT content and aspect ratio, surfactants, sonication time and power, water-tocement ratio [49]. The most remarkable improvement was achieved by Al-Rub et al. [49], who reported $269 \%$ improvement of flexural strength by adding $0.2 \mathrm{wt} \%$ short MWCNTs. Using the experimental procedures and results from Al-Rub et al., we estimate the life cycle net energy benefit from additions of MWCNTs in cement as highway construction material.

The improvement in flexural strength could result in a reduction of required thickness of concrete, as the reinforced concrete could achieve an equivalent mechanical strength with less material. For example, $300 \%$ improvement (four times of original value) of flexural strength could result in $50 \%$ reduction of thickness [50]. Calculations indicate that a $269 \%$ improvement could result in a $48 \%$ reduction of thickness, (i.e., 48\% less concrete needed). The experimental settings in Al-Rub et al. [49] included: MWCNT concentration of $0.2 \mathrm{wt} \%$ of cement; a water-to-cement ratio of 0.4 ; and a surfactant use equal to $0.4 \mathrm{wt} \%$ of cement. The amount of materials used and related embodied energies are listed in Table 3. 
Table 3: Net energy benefit assumptions-MWCNT reinforced cement, baseline CNT scenario

\begin{tabular}{|c|c|c|c|c|}
\hline & Parameter & $\begin{array}{l}\text { MWCNT-enabled } \\
\text { cement }\end{array}$ & $\begin{array}{l}\text { Conventional } \\
\text { cement }\end{array}$ & Ref. \\
\hline \multirow[t]{6}{*}{$\begin{array}{l}\text { Manufacturing } \\
\text { phase }\end{array}$} & Flexural strength improvement & $269 \%$ & Reference point & $\begin{array}{l}{[48,} \\
49]\end{array}$ \\
\hline & Mass required $(\mathrm{kg})$ & $\begin{array}{l}\text { Cement: 1,000 } \\
\text { MWCNTs: } 2 \\
\text { Surfactant: } 4\end{array}$ & 1921 & \\
\hline & $\begin{array}{l}\text { Energy requirement per unit } \\
(\mathrm{MJ} / \mathrm{kg})\end{array}$ & $\begin{array}{l}\text { Cement: } 3.8^{A} \\
\text { MWCNTs: } 940^{B} \\
\text { Surfactant: } 30^{C}\end{array}$ & Cement: $3.8^{\mathrm{A}}$ & $\begin{array}{l}{[26,} \\
43]\end{array}$ \\
\hline & Energy requirement (MJ) & 5,800 & 7299 & \\
\hline & $\begin{array}{l}\text { Avoided energy requirement in } \\
\text { material (MJ) }\end{array}$ & 1,500 & & \\
\hline & $\begin{array}{l}\text { Additional energy requirement in } \\
\text { dispersion (MJ) }\end{array}$ & $-1,150$ & & \\
\hline Use phase & Not applicable & & & \\
\hline Life cycle & Net energy benefit (MJ) & 350 & & \\
\hline
\end{tabular}

A: $3.8 \mathrm{MJ} / \mathrm{kg}$ for cement from the ecoinvent v2.2 database (Portland cement, strength class Z42.5, at plant) [43]. B: $940 \mathrm{MJ} / \mathrm{kg}$ for MWCNTs from Kushnir and Sanden using floating catalyst CVD method [26].

C: $30 \mathrm{MJ} / \mathrm{kg}$ for surfactant is reported by the ecoinvent $\mathrm{v} 2.2$ database (polycarboxylate, $40 \%$ active substance, at plant) [43].

Dispersion of MWCNTs into cement homogeneously is crucial to improve concrete strength. MWCNTs were dispersed using an ultrasonic wave mixer in water with surfactant (the authors [49] chose to use a type of superplasticizer-polycarboxylate) at room temperature. The ultrasonication process characteristics assumed for this analysis are listed in Table 4. The additional energy requirement during dispersion would be $-1,150 \mathrm{MJ}$ to mix $2 \mathrm{~kg}$ MWCNTs into $400 \mathrm{~kg}$ water. Combined with the result of avoided energy requirement in materials, the total net energy benefit by adding MWCNTs to 1,000 kg cement would be $350 \mathrm{MJ}$.

A crucial parameter in this analysis is the strength improvement. Although Abu Al-Rub et al. [49] reported $269 \%$ flexural strength improvement, other reported results differ, e.g., Luo et al. [51] reported $35 \%$ improvement with the same $0.2 \mathrm{wt} \%$ MWCNTs. The reasons for the difference were claimed to be due to various other experimental settings [49] Hence in the uncertainty analysis for this study, we explored the range of strength improvements (Section 5).

Table 4: Inputs for dispersion of $2 \mathrm{~kg}$ MWCNTs into $400 \mathrm{~kg}$ water during ultrasonication

\begin{tabular}{|lrr|}
\hline Parameter & Value & Ref. \\
\hline Power (W per $\mathbf{~ m l ~ w a t e r ) ~}$ & 0.46 & {$[49]$} \\
\hline Time (hour) & 0.50 & {$[49]$} \\
\hline Energy use (kWh per I water) & 0.23 & \\
\hline Additional energy requirement (MJ/2 kg CNTs) & $-1,150$ & \\
\hline
\end{tabular}




\subsubsection{Use phase}

The use phase in this case is assumed to have no energy requirements for either the MWCNT-enabled cement or the conventional cement.

\subsubsection{Net energy benefits}

There appears to be a slight benefit of $350 \mathrm{MJ}$ for the base case assumption. Additional analyses are undertaken in Section 5.

\subsection{SWCNT switches in 16 Gb flash memory}

Due to their unique mechanical and electrical properties, SWCNTs demonstrate great promise to act as electromechanical switches to replace conventional silicon-based switches in memory storage devices [52]. The ability to operate at low voltage could potentially save energy when using CNT switches in electronic devices. However, fabrication of CNTs into the devices could require additional energy.

Dahlben et al. published a LCA study of CNTs switches for use in flash memory of cell phones [53]. According to the authors, the CNT-enabled switches could replace the floating gate metal-oxidesemiconductor field-effect transistor (FGMOSFET) currently used in the NAND (binary logic operation of Not AND) flash memory of cell phones. The fabrication processes were described in details in the patent filing [52].

\subsubsection{Manufacturing phase}

Production of CNT switches includes typical semiconductor fabrication processes and special processes (including metallization of gold ( $\mathrm{Au}$ ) electrodes and CNT deposition). Dahlben et al. found that the metallization of gold electrodes consumed intensive energy, because of the high electricity requirement to run the e-beam evaporator and sputter deposition system. The total fabrication energy use is 13.1 kWh per 3-inch wafer (where metallization requires $9.5 \mathrm{kWh}$ ). Fabrication of a $16 \mathrm{~Gb}$ of memory device would require 12 wafers in total for lab-scale settings. Additionally, the energy requirement embodied in gold electrodes is high. The amount of gold required in metallization is high at $1.4 \mathrm{~g}$ Au for one 3-inch wafer [53].

The actual amount of SWCNTs used in one memory device is trivial. Dahlben et al. estimated that 6 to 48 g CNTs are used to produce $16 \mathrm{~Gb}$ memory in about 100 million cell phones [53]. We used the upper bound ( $48 \mathrm{~g}$ ) to calculate $5 \mathrm{E}-07 \mathrm{~g}$ per $16 \mathrm{~Gb}$ memory. The resulting embodied energy of SWCNTs in the flash memory is approximately $1 \mathrm{MJ}$. Compared with the embodied energy contribution of other components, it is negligible $[53,54]$.

The LCA study of NAND flash memory published by Boyd et al. [55] shows that the energy requirement per $8 \mathrm{~Gb}$ ( $8 \mathrm{~Gb}$ storage capacity per die) is $47 \mathrm{MJ}$ for fabrication and $6 \mathrm{MJ}$ for chemicals (from the 
'expected value' of their Table 3 [55]). To equate with a SWCNT flash memory of 16 Gb capacity, we doubled the numbers for NAND to $94 \mathrm{MJ}$ and $12 \mathrm{MJ}$, respectively.

Table 5 compares SWCNT switches and conventional NAND switches used in 16 Gb flash memory.

\subsubsection{Use phase}

According to the information on power use, operation time and the number of switches used [53], we calculated the electricity use of one operation cycle. To evaluate the electricity use for the entire lifespan for flash memory used in a cell phone, we assumed an average service life of three years. We also assumed that full capacity of the flash memory (16 Gb) is used each time (one operation cycle). Hence, each SWCNT switch in its lifetime will be operated 1,095 times. Given the energy use of one cycle and total cycle numbers, we calculated the electrical energy use of the memory device during its lifespan. After electricity-to-primary energy conversion, the energy requirement of the use phase for 16 Gb memory using SWCNT switches is $2 \mathrm{E}-05 \mathrm{MJ}$, while the result for conventional flash memory device is 12,610 MJ. This results because (as listed in Table 5), both the power use and time use of SWCNT switches are several orders of magnitude less than the conventional switches.

\subsubsection{Net energy benefit}

Combining the results of the manufacturing phase and the use phase, the life cycle energy benefit from using SWCNT switches to replace conventional FGMOSFET in $16 \mathrm{~Gb}$ flash memory is 5,990 MJ. The main assumption in this case study is the service lifespan of flash memory, which is limited by technical obsolescence of the cell phone, but not by the physical lifespan of the flash memory, which could be much longer than three years. The lifetime assumption is revisited in the uncertainty analysis of this case study (Section 5).

Table 5: Net energy benefit assumptions-SWCNT switches, baseline CNT scenario

\begin{tabular}{|c|c|c|c|c|}
\hline & Parameter & SWCNT switch & $\begin{array}{l}\text { Conventional NAND } \\
\text { switch }\end{array}$ & Ref. \\
\hline \multirow[t]{4}{*}{$\begin{array}{l}\text { Manufacturing } \\
\text { phase }\end{array}$} & Energy use in fabrication (MJ) & $\begin{aligned} & 1,868 \\
& \bullet 1354 \\
& \text { (metallization) } \\
& \bullet 428 \text { (etching) } \\
& \bullet 86 \text { (other) } \\
&\end{aligned}$ & 94 & {$[53,55]$} \\
\hline & $\begin{array}{l}\text { Energy embodied in materials } \\
\text { (MJ) }\end{array}$ & $\begin{aligned} & 4,778 \\
& \bullet 4638 \text { (gold) } \\
& \bullet 1(\text { SWCNTs) } \\
& \bullet 139 \text { (other) } \\
&\end{aligned}$ & 12 & {$[53,55]$} \\
\hline & Total energy requirement (MJ) & 6,646 & 106 & \\
\hline & $\begin{array}{l}\text { Additional energy requirement } \\
\text { (MJ) }\end{array}$ & $-6,540$ & & \\
\hline Use phase & $\begin{array}{l}\text { Electricity use of one operation } \\
\text { cycle to process } 16 \mathrm{~Gb} \text { data } \\
\text { (kWh) }\end{array}$ & $\begin{aligned} \text { 1E-09 } & \\
\text { - } & 9 \mathrm{E}-07 \text { Watt } \\
& \text { (power) } \\
\text { - } & 4 \mathrm{E}-08 \text { second }\end{aligned}$ & $\begin{array}{cl}9.3 \mathrm{E}-01 & \\
\bullet & 6.6 \mathrm{E}-03 \mathrm{Watt} \\
& \text { (power) } \\
\bullet & 2.3 \mathrm{E}-03\end{array}$ & {$[53]$} \\
\hline
\end{tabular}




\begin{tabular}{|c|c|c|c|}
\hline & & $\begin{array}{ll}\text { (time) } \\
1.5 \mathrm{E}+11 \\
\text { (number of } \\
\text { switches) }\end{array}$ & $\begin{array}{ll} & \text { second (time) } \\
2.2 \mathrm{E}+11 \\
\text { (number of } \\
\text { switches) }\end{array}$ \\
\hline & $\begin{array}{l}\text { (Main assumption) } \\
\text { Total cycle numbers in the } \\
\text { lifespan of memory device }\end{array}$ & $1,095$ (3 years $* 365)$ & $1,095(3$ years $* 365)$ \\
\hline & Total energy requirement (MJ) & $2 \mathrm{E}-05$ & 12,610 \\
\hline & $\begin{array}{l}\text { Avoided energy requirement } \\
\text { (MJ) }\end{array}$ & 12,610 & \\
\hline Life cycle & Total energy requirement (MJ) & 6,623 & 12,174 \\
\hline & Net energy benefit (MJ) & 5,990 & \\
\hline
\end{tabular}

A: It requires $16.8 \mathrm{~g}$ gold, and 276,094 MJ/kg embodied energy for gold is reported by ecoinvent $\mathrm{v} 2.2$ database (gold at refinery, at plant) [43].

\subsection{CNT electrodes in Li-ion batteries}

Due to their electrochemical properties, CNTs have been receiving considerable attention as a candidate material for batteries. In this case study, we investigated the net energy benefit of both manufacturing and use phases of CNT-enabled Li-ion batteries to power electric vehicles. The conventional anode material is graphite and conventional cathode material is carbon black (as an additive to lithium metal oxide) [56, 57] CNTs could act as an alternative anode material [7] and/or a cathode additive [58]. The reversible specific capacity for SWCNT anodes can exceed 1,000 mAh/g (theoretical), compared with 370 $\mathrm{mAh} / \mathrm{g}$ (theoretical) for conventional graphite anodes [44]. However, the actual prospective achievements of reversible specific capacity for SWCNT anodes fall between 300 and $600 \mathrm{mAh} / \mathrm{g}$ [7, 44]. In addition to high energy capacity, SWCNTs have the capability to be assembled into free-standing electrodes to eliminate the use of binders and current collectors, which would reduce the weight of the battery $[44,56]$. For the cathode additive material, MWCNTs could replace carbon black to achieve higher specific capacity and at the same time eliminate the use of binders [58,59]. With lighter weight CNT Li- ion batteries, energy consumption during the use phase of vehicles could be reduced. However, production of CNTs adds an 'additional energy requirement' in the manufacturing phase.

In this analysis, we investigated net energy benefit for two battery designs: 1 ) using SWCNTs to replace graphite as anode (Table 6); and 2) using MWCNTs to replace carbon black as cathode additive (Table 7).

\subsubsection{Manufacturing phase}

For the SWCNT anode case, an important electrochemical characteristic is the improvement of specific capacity. The specific capacity for the graphite anode (not considering the weight of binder) is about 330 $\mathrm{mAh} / \mathrm{g}$ (practical) [44]. If the SWCNT anode could achieve $600 \mathrm{mAh} / \mathrm{g}$ specific capacity, then the improvement would be $80 \%$. To achieve the same capacity (in this case, we assume a $16 \mathrm{kWh}$ battery), the anode requires less active material when using SWCNTs, which also saves mass for anode binder, anode current collector, and auxiliary components. To calculate the weight of each component, we utilized the model BatPac V2.2 developed by US DOE Argonne National Laboratory [60]. 
For the case of the MWCNT cathode, the improvement in specific capacity is also a crucial characteristic. The active cathode material assumed for this study is lithium-nickel-manganese-cobalt oxide (NMC or NCM), because of its favorable power capacity and thermal safety characteristics for electric vehicle applications [57, 61]. Varzi et al. [58] reported that using MWCNTs to replace part of the carbon black in NMC cathodes could bring enhancement of the rate capability (i.e., the specific capacity at different levels of discharge rate). In this study, we only considered the recommended discharge C-rate (i.e., the time for cell discharge in reciprocal hours), which is $1 \mathrm{C}$ (i.e., it discharges in 1 hour). The discharge capacity improvement of NMC cathodes by adding 1 wt\% MWCNTs increased from 125 to $130 \mathrm{mAh} / \mathrm{g}$ at 1C (from their Fig.6 [58]). Shah et al. [62] reported that a Li-rich NMC with a four-layered structure of MWCNTs could improve discharge capacity by around 8\% at 1C (from their Fig.7b). Just as for SWCNT anodes, MWCNT cathodes could also eliminate the use of binders. To calculate the weight of each component, we utilized the model BatPac V2.2 developed by US DOE Argonne National Laboratory [60].

\subsubsection{Use phase}

By using CNTs, the total mass of materials (e.g., electrodes, cell container, and battery jacket) in the battery will be reduced. In the anode case, the total weight reduction of the $16 \mathrm{kWh}$ battery is $19 \mathrm{~kg}$; and in the cathode case, the total weight reduction is $6.6 \mathrm{~kg}$ (with calculations performed in BatPac V2.2 [60]). Based on earlier work, the reduction in energy use in a battery electric vehicles as a function of weight savings is approximately $1.78 \mathrm{kWh} /(100 \mathrm{~km} * 100 \mathrm{~kg})[63]$. We apply this factor over the entire battery lifespan, with vehicle miles traveled assumed at 160,000 km. (The warranty mileage for Nissan LEAF® Li-ion battery is $160,000 \mathrm{~km}$ [64].) With these values, the use phase primary energy reduction for the anode case is calculated to be 6,709 MJ, and for the cathode case is 2,330 MJ.

\subsubsection{Net energy benefit}

Table 6 compiles each attribute of energy use in the manufacturing and use phases to compare batteries with SWCNT anodes and graphite anodes. Base case results indicate that there is a net energy deficit of $14,716 \mathrm{MJ}$.

Table 7 tabulates the attributes of energy use for MWCNT cathodes ( 1 wt \% MWCNTs and 4 wt\% carbon black) and carbon black ( $5 \mathrm{wt} \%$ ) cathodes. In this case, results suggest that there is a net energy benefit of $2775 \mathrm{MJ}$.

In the analyses shown in Table 6 and Table 7, two key assumptions influence the results: one is the relationship between energy use and vehicle weight; the other is the assumed service lifespan of the battery. In the uncertainty analysis of this study (Section 5), a range of values for these two parameters is explored.

Table 6: Net energy benefit assumptions-SWCNT anodes in Li-ion batteries, baseline CNT scenario

$$
\text { SWCNTs anode }
$$




\begin{tabular}{|c|c|c|c|c|}
\hline \multirow{7}{*}{$\begin{array}{l}\text { Manufacturing } \\
\text { phase }\end{array}$} & Specific capacity (mAh/g) & 600 & 330 & {$[7,44]$} \\
\hline & Mass required $(\mathrm{kg})$ & 9.2 & 16.8 & \\
\hline & Embodied energy per unit (MJ/kg) & $2,487^{A}$ & $68^{B}$ & {$[26,43]$} \\
\hline & $\begin{array}{l}\text { Energy requirement of anode } \\
\text { active material (MJ) }\end{array}$ & 22,917 & 1,142 & \\
\hline & $\begin{array}{l}\text { Additional energy requirement in } \\
\text { anode active material (MJ) }\end{array}$ & $-21,774$ & & \\
\hline & $\begin{array}{l}\text { Avoided energy requirement in } \\
\text { other components (MJ) }\end{array}$ & $\begin{array}{r}350 \\
\stackrel{\bullet}{\bullet} \\
\bullet \\
\bullet \\
\bullet \\
\bullet\end{array}$ & $\begin{array}{l}\text { inder) } \\
\text { rrent collector) } \\
\text { iner) } \\
\text { conductor) } \\
\text { on plates) } \\
\text { cket) }\end{array}$ & \\
\hline & $\begin{array}{l}\text { Additional energy requirement } \\
\text { (MJ) }\end{array}$ & $-21,425$ & & \\
\hline \multirow[t]{4}{*}{ Use phase } & $\begin{array}{l}\text { 16kWh battery weight reduction } \\
(\mathrm{kg})\end{array}$ & 19 & & \\
\hline & $\begin{array}{l}\text { (Main assumption) } \\
\text { Energy reduction value } \\
(\mathrm{kWh} / 100 \mathrm{~km} * 100 \mathrm{~kg})\end{array}$ & 1.78 & & {$[63]$} \\
\hline & $\begin{array}{l}\text { (Main assumption) } \\
\text { Battery lifespan travel distance } \\
(\mathrm{km})\end{array}$ & 160,000 & & \\
\hline & Avoided energy requirement (MJ) & 6709 & & \\
\hline Life cycle & Net energy benefit (MJ) & $-14,716$ & & \\
\hline
\end{tabular}

A: $2487 \mathrm{MJ} / \mathrm{kg}$ for SWCNTs is reported by Kushnir and Sanden using fluidized bed CVD method [26].

B: $68 \mathrm{MJ} / \mathrm{kg}$ for graphite is reported by ecoinvent v2.2 database (graphite battery grade at plant) [43].

Table 7: Net energy benefit assumptions-MWCNT cathode in Li-ion batteries, baseline CNT scenario

\begin{tabular}{|c|c|c|c|c|}
\hline & Parameter & MWCNT cathode & $\begin{array}{l}\text { Conventional } \\
\text { carbon black } \\
\text { cathode }\end{array}$ & Ref. \\
\hline \multirow{6}{*}{$\begin{array}{l}\text { Manufacturing } \\
\text { phase }\end{array}$} & Specific capacity (mAh/g) & 130 & 125 & [58] \\
\hline & Mass required $(\mathrm{kg})$ & \multicolumn{2}{|l|}{ MWCNTs: 0.38} & \\
\hline & Embodied energy per unit (MJ/kg) & $\begin{array}{l}\text { MWCNTs: } 940^{\mathrm{A}} \\
\text { Carbon black: } 89^{\mathrm{D}}\end{array}$ & $89^{B}$ & [43] \\
\hline & $\begin{array}{l}\text { Energy requirement of cathode } \\
\text { active material (MJ) }\end{array}$ & 498 & 291 & \\
\hline & $\begin{array}{l}\text { Additional energy requirement in } \\
\text { cathode active material (MJ) }\end{array}$ & \multicolumn{3}{|l|}{-207} \\
\hline & $\begin{array}{l}\text { Avoided energy requirement in } \\
\text { other components (MJ) }\end{array}$ & \multicolumn{3}{|l|}{$\begin{aligned} 651 & \\
\text { - } & 101 \text { (catho } \\
\text { - } & 522 \text { (catho } \\
\text { - } & 2 \text { (anode } \mathrm{cl} \\
\text { - } & 5 \text { (cell cont }\end{aligned}$} \\
\hline
\end{tabular}




\begin{tabular}{|c|c|c|}
\hline & & $\begin{array}{l}\text { - } 9 \text { (aluminum conductor) } \\
\text { - } 2 \text { (compression plates) } \\
\text { - } \quad 10 \text { (battery jacket) }\end{array}$ \\
\hline & Avoided energy requirement (MJ) & 444 \\
\hline Use phase & $\begin{array}{l}\text { 16kWh battery weight reduction } \\
(\mathrm{kg})\end{array}$ & 6.6 \\
\hline & $\begin{array}{l}\text { (Main assumption) } \\
\text { Energy reduction value }(\mathrm{kWh} / 100 \\
\mathrm{km} * 100 \mathrm{~kg})\end{array}$ & 1.78 \\
\hline & $\begin{array}{l}\text { (Main assumption) } \\
\text { Battery lifespan travel distance } \\
(\mathrm{km})\end{array}$ & 160,000 \\
\hline & Avoided energy requirement (MJ) & 2330 \\
\hline $\begin{array}{l}\text { Manufacturing } \\
\text { and use phases }\end{array}$ & Net energy benefit (MJ) & 2775 \\
\hline
\end{tabular}

A: $940 \mathrm{MJ} / \mathrm{kg}$ for MWCNTs is the reported by Kushnir and Sanden using floating catalyst CVD method [26]. B: $89 \mathrm{MJ} / \mathrm{kg}$ for carbon black is reported by ecoinvent v2.2 database [43].

\section{Uncertainty analysis}

To calculate life cycle net energy benefits, baseline assumptions were made in each of the case studies investigated, and the uncertainty in each of the assumptions listed in Table 8 is examined to determine its effect on the results. This type of uncertainty is identified as a parameter uncertainty (other types of uncertainties could include model uncertainty, temporal or spatial uncertainties) $[65,66]$. Because there is enormous variability in the energy requirement for CNT production (the value of the baseline scenario is about three times the value of the efficient scenario), each of these two scenarios is utilized in the three case studies. In each case study, the most important uncertain parameter is explored. For the flexural strength improvement of cement, the most remarkable increase was reported as $269 \%$ with the addition of MWCNTs, however, only one report cites that increase. So a range of the flexural strength from $169 \%$ to $369 \%$ (normal distribution $\mu=269 \%, \sigma=100 \%$ ) is analyzed. For the service lifespan of cell phones, three years is arbitrary; phones are frequently upgraded and replaced in three years' time. The service lifespan of CNT-enabled Li-ion batteries is based on a 160,000 km warranty for vehicle miles traveled (VMT) for the Nissan LEAF® battery, which could be considered as a reasonable reference. For the energy reduction per unit of weight savings, $1.78 \mathrm{kWh} /(100 \mathrm{~km} * 100 \mathrm{~kg})$ is the mean value of the reported results as previously discussed. Each parameter that is listed in Table 8 was assigned a normal distribution for which the $90 \%$ confidence interval covers a reasonable (yet subjective) range, e.g., 2 years to 4 years for cell phone lifespan. A Monte Carlo simulation was carried out for each case study (10,000 runs), with net energy benefit (MJ/ product) results shown in Figure 2 for the baseline scenario and in Figure 3 for the efficient scenario.

Table 8: Summary of uncertainty analysis of input parameters

\begin{tabular}{|c|c|}
\hline Case studies & Parameter \\
\hline
\end{tabular}




\begin{tabular}{|lllll|}
\hline All & $\begin{array}{l}\text { Energy requirements of } \\
\text { CNT production }\end{array}$ & Scenario analysis & Baseline; Efficient & NA \\
\hline Cement & $\begin{array}{l}\text { Flexural strength } \\
\text { improvement }\end{array}$ & $\begin{array}{l}\text { Monte Carlo } \\
\text { simulation }\end{array}$ & $\begin{array}{l}\text { normal distribution } \\
\mu=269 \%, \sigma=100 \%\end{array}$ & $(105 \%, 433 \%)$ \\
\hline \multirow{2}{*}{ Flash memory } & $\begin{array}{l}\text { Service lifespan of cell } \\
\text { phone }\end{array}$ & $\begin{array}{l}\text { Monte Carlo } \\
\text { simulation }\end{array}$ & $\begin{array}{l}\text { normal distribution } \\
\mu=3 \text { yrs, } \sigma=0.6\end{array}$ & $(2.01,3.99)$ \\
\hline \multirow{2}{*}{ Li-ion battery } & $\begin{array}{l}\text { Service lifespan of } \\
\text { battery }\end{array}$ & $\begin{array}{l}\text { Monte Carlo } \\
\text { simulation }\end{array}$ & $\begin{array}{l}\text { normal distribution } \\
\mu=160,000 \mathrm{~km}, \sigma=16,000\end{array}$ & $(134,186)$ \\
\cline { 2 - 5 } & $\begin{array}{l}\text { Energy reduction value } \\
\text { of (mid-size) vehicle }\end{array}$ & $\begin{array}{l}\text { Monte Carlo } \\
\text { simulation }\end{array}$ & $\begin{array}{l}\text { normal distribution } \\
\mu=1.78, \sigma=1\end{array}$ & $(0.78,2.78)$ \\
& & & & \\
\hline
\end{tabular}

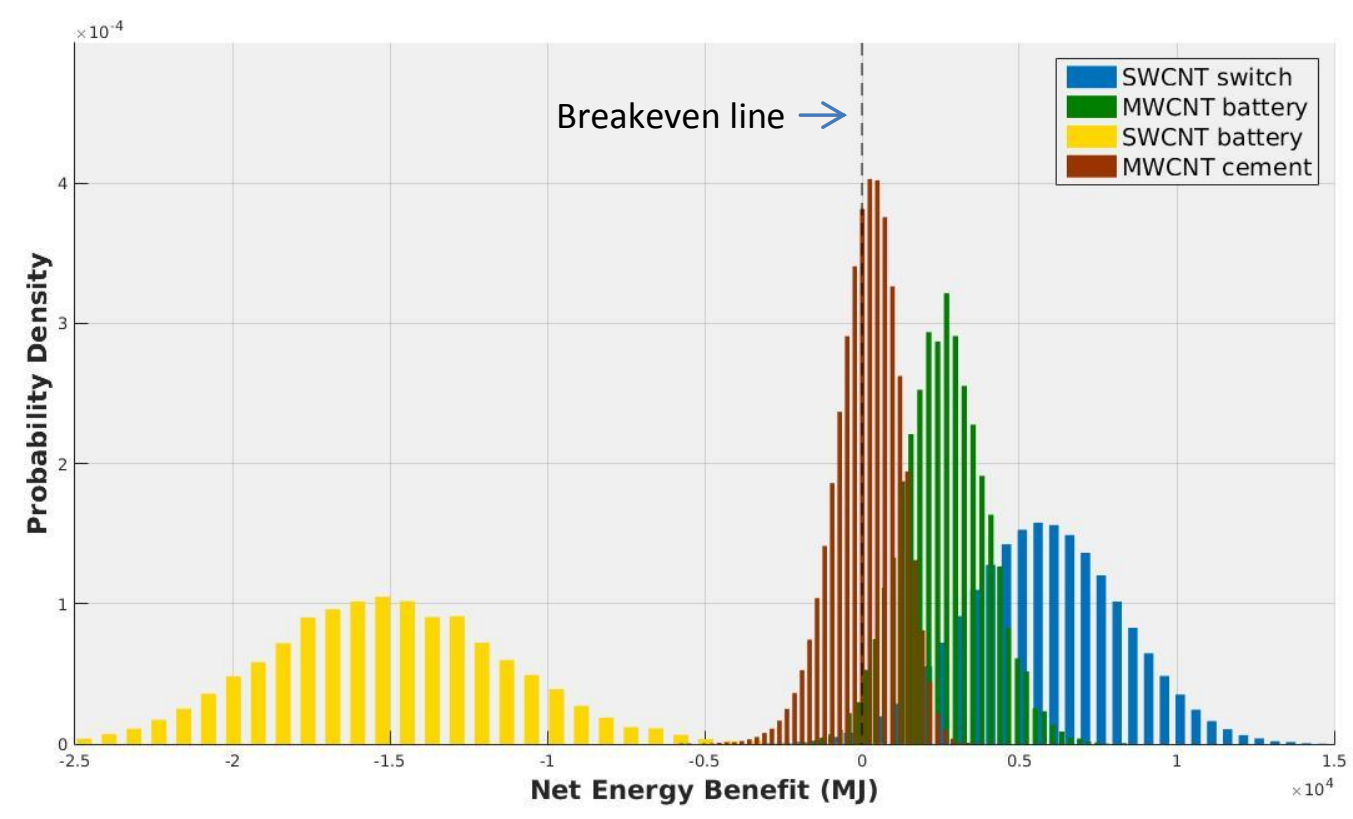

Figure 2: Distribution of net energy benefits-Baseline scenario (to the right of the Breakeven line has positive net energy) 


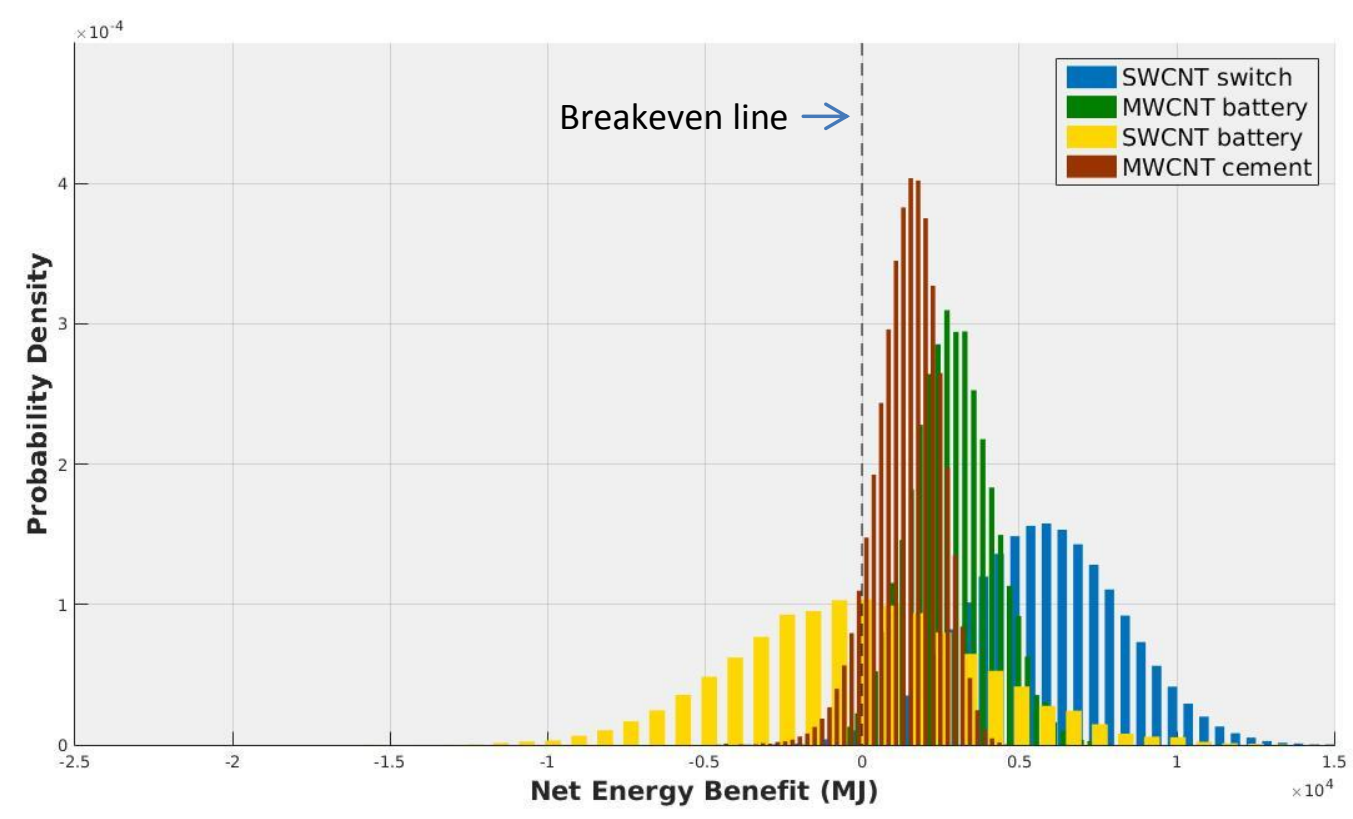

Figure 3: Distribution of net energy benefits-Efficient scenario (to the right of the Breakeven line has positive net energy)

The uncertainty distributions of each parameter generated distributions of net energy benefit for each case study. Figure 2 and Figure 3 identify the applications that trend toward positive net energy benefit and which applications appear to be negative. Table 9 summarizes the statistical results for the net energy benefits of each application, using one-tailed $z$-tests of confidence level of $95 \%(\alpha=0.05)$ to test the probability that the true mean value of the results is above (positive benefits) or below the breakeven line.

Table 9: Statistical summary of Monte Carlo simulation results

\begin{tabular}{|c|c|c|c|c|}
\hline \multirow[b]{2}{*}{ CNT applications } & \multicolumn{2}{|c|}{ Baseline scenario } & \multicolumn{2}{|c|}{ Efficient scenario } \\
\hline & $\begin{array}{l}\text { One-tailed test } \\
\text { Baseline CNTs }\end{array}$ & $P$-value & $\begin{array}{l}\text { One-tailed test } \\
\text { Efficient CNTs }\end{array}$ & $P$-value \\
\hline $\begin{array}{l}\text { MWCNT reinforced cement } \\
\text { (1m of 4-lane highway) }\end{array}$ & Positive & 0.44 & Positive & 0.08 \\
\hline $\begin{array}{l}\text { SWCNT switch flash memory } \\
\text { (16 Gb used in cell phones) }\end{array}$ & Positive & $<0.01$ & Positive & $<0.01$ \\
\hline $\begin{array}{l}\text { SWCNT Li-ion battery anodes } \\
\text { (16 kWh used in vehicles) }\end{array}$ & Negative & $<0.01$ & Positive & 0.37 \\
\hline $\begin{array}{l}\text { MWCNT Li-ion battery cathodes } \\
\text { (16 kWh used in vehicles) }\end{array}$ & Positive & $<0.01$ & Positive & $<0.01$ \\
\hline
\end{tabular}

\section{Discussion}


The results in Figure 2 and Figure 3 indicate that not all of the applications provide a net energy benefit, based on the uncertainty analyses of assumptions. SWCNT switch flash memory used in cell phones brings positive net energy benefits in both scenarios, as most of its distribution lies to the right of zero for both scenarios. The results for MWCNT-reinforced cement are not statistically significant at $\alpha=0.05$ in either scenario, although positive benefits are more likely for the efficient scenario. For batteries, SWCNT Li-ion anodes result in significant negative net energy value in the baseline scenario, but do not show significant negative or positive result in the efficient scenario. MWCNT cathodes, on the other hand, result in positive results for both CNT production scenarios. Analyses for these four applications indicate that the use of carbon-based nanomaterials such as CNTs may not always bring life cycle energy benefits. Rather, these must be assessed on a case-by-case basis, and are dependent on the performance improvements, the patterns of use, and the scenarios of the embodied energy of CNTs.

One hypothesis of this work is that net energy benefit is related to the concentration or weight percentage of CNTs. The mass of one flash memory is about $2.8 \mathrm{~g}$, containing $5 \mathrm{E}-07 \mathrm{~g} \mathrm{CNT}$, so the weight percentage is quite small at $0.00002 \%$. The CNT Li-ion batteries assessed in our study weigh about $110 \mathrm{~kg}$. For the SWCNT anode, the CNT mass is $9 \mathrm{~kg}$, and for the battery with the MWCNT cathode, the CNT mass is $0.4 \mathrm{~kg}$, so the weight percentages of the total battery are $8 \%$ and $0.3 \%$, respectively. For $1,000 \mathrm{~kg}$ of concrete, $2 \mathrm{~kg}$ of MWCNTs are used, resulting in a weight percentage of $0.2 \%$. Applications with low CNT concentrations (e.g., flash memory) tend to have a higher net energy benefit, as shown in Table 10. This is likely due to the function that CNTs provide in each application. Bulk use of CNTs for their mechanical properties (as in concrete) may achieve energy savings only through avoided material use and require significant energy for CNT production, whereas incorporation of CNTs into specialized electronic components tends to use small amounts and can greatly improve performance and reduce energy use directly.

Table 10: Relationship of net energy benefits and CNT weight percentage (in ascending order of concentration), CNT production energy baseline value

\begin{tabular}{|lcl|}
\hline CNT applications & $\begin{array}{l}\text { Net energy } \\
\text { benefit mean } \\
\text { value (MJ) }\end{array}$ & $\begin{array}{l}\text { CNT } \\
\text { concentration } \\
\text { (wt\%) }\end{array}$ \\
\hline $\begin{array}{l}\text { SWCNT switch flash memory } \\
\text { (16 Gb used in cell phones) }\end{array}$ & 5,990 & $0.00002 \%$ \\
\hline $\begin{array}{l}\text { MWCNT-reinforced cement } \\
\text { (1 m of 4-lane highway) }\end{array}$ & 351 & $0.2 \%$ \\
\hline $\begin{array}{l}\text { MWCNT Li-ion battery cathodes } \\
\text { (16 kWh used in vehicles) }\end{array}$ & 2,775 & $0.3 \%$ \\
\hline $\begin{array}{l}\text { SWCNT Li-ion battery anodes } \\
\text { (16 kWh used in vehicles) }\end{array}$ & $-14,716$ & $8.0 \%$ \\
\hline
\end{tabular}

These results can be compared with other published studies of potential energy benefits of nanomaterials. Arvidsson et al. reported 3-10 times reduction of energy requirement when implementing graphene as a substitute for indium tin oxide in transparent electrodes [67]. Wender and Seager [29] reported negative energy benefit (between 45 and $130 \mathrm{MWh}$ of additional electricity per 
kWh of battery storage capacity) in the manufacturing phase of SWCNT anodes in Li-ion batteries. Our results show that even including the energy benefits generated during the use phase for electric vehicles, the net energy benefit remains negative. Researchers have been working on many other anode alternatives [68], e.g., silicon nanowires [69], metal oxides and MWCNT composites [57], as well as graphene and hybrid structures [70]. Li et al. [69] reported that using silicon nanowire to replace graphite could also result in negative net energy benefit, where the energy requirements for graphite battery are $0.46 \mathrm{MJ} / \mathrm{km}$ for battery production and $1.68 \mathrm{MJ} / \mathrm{km}$ for battery use; while for a silicon nanowire battery these numbers are $1.96 \mathrm{MJ} / \mathrm{km}$ and $1.47 \mathrm{MJ} / \mathrm{km}$, respectively (from Table S246 in their Supporting Information [69]). From the perspective of net energy analysis, the use of nanomaterials to replace the graphite anode may not be promising. On the other hand, the use of MWCNTs as cathode additives shows positive net energy benefit. In addition to the energy benefit, MWCNTs are touted to improve other characteristics of batteries, e.g., rate capability (higher power density when discharged quickly) and cycle life (less loss after many cycles to provide a longer lifetime) [57, 62].

The results are presented on a functional unit basis, but can be scaled up to consider prospective largescale deployment of CNT-enabled devices, acknowledging attendant uncertainties in doing so. For example, the forecasting deployment of world-wide electric vehicles using Li-ion batteries in 2017 is about seven million [71]. If only $1 \%$ of these batteries utilize MWCNT-enabled cathodes, then the avoided energy compared with conventional Li-ion batteries would be $194 \mathrm{TJ}$ (using the unit factor from Table 7, 16\% from manufacturing and $84 \%$ from use). With the assumption that the avoided electricity originates from the average U.S. grid with a carbon intensity of $690 \mathrm{~g} \mathrm{CO}_{2}$ emission per $\mathrm{kWh}$ [72], the avoided $\mathrm{CO}_{2}$ emission would be about 10,800 metric tons, equivalent to annual electricity use for nearly 1,500 U.S. homes.

Although the possible hazards from CNTs are not addressed in this analysis, health and safety issues must be included in the discussion. It is clear that the health of workers and the general public must not be compromised to achieve an energy benefit. The environmental health and safety implications of CNTs have been extensively explored. Because there are so many CNT variations, there are no definitive results, however, the U.S. National Institute of Occupational Safety and Health (NIOSH) has proposed a recommended exposure limit (REL) of $1 \mu \mathrm{g} / \mathrm{m}^{3}$ elemental carbon as a respirable mass 8-hour timeweighted average concentration.[20] NIOSH has also developed best practices for controlling workplace exposures. Although hazardous materials might be utilized in the workplace, industry can work safely with CNTs to reduce exposes and the risk for pulmonary inflammation and fibrosis. Commercialization would require implementation of best workplace practices to avoid the hazards, and to glean the benefits associated with various nano-enabled products. The US Consumer Product Safety Commission (CPSC) has also been addressing issues of quantifying exposure to engineered nanomaterials from manufactured goods from the perspective of consumer use [73]. There are no recommendations as yet for the CNT-enabled products in our case studies, however, recycling infrastructures and or product stewardship can play a direct roles in avoiding exposures while leveraging product benefits.

For the application of MWCNT cement, although both scenarios show positive energy benefits, this application poses potentially unclear health impacts. MWCNTs are (nearly) evenly dispersed in concrete, which is directly exposed to environment without any protection. It is possible that CNTs could be 
released to the environment through road wear, causing human exposure during heavy use, highway maintenance, or grinding for aggregate reuse.

For the application of cell phones and Li-ion batteries, CNT releases are unlikely during the use phase. In end-of-life (EOL) management, there are three ways that electronic waste could be treated: 1 ) recovery and recycling; 2) direct disposal to landfill or 3) incineration. Shredding and crushing during recycling may generate dust, and it is likely that CNTs could become dispersed in the air and cause occupational exposure [74]. However, as noted above, the concentration of CNTs is extremely low in cellphones and many other consumer electronics where CNTs are being used as conductive material. Direct disposal of intact cell phones to landfills is unlikely to release CNTs to the environment, although if shredded materials are subsequently landfilled there may be pathways that lead to exposure. For electronic waste incineration above $740^{\circ} \mathrm{C}$ under oxidative conditions, CNTs could burn off completely $[75,76]$.

Another issue to be noted is that although the energy requirement for CNT production cited in this study from Kushnir and Sanden [26] is based on commercial-scale production assumptions, all three of the applications investigated are still at lab-scale. When scaling-up to high volume manufacturing, the material choice and production efficiency would change. For example, for the application of SWCNT flash memory devices, the electrodes could use tungsten rather than gold [54], resulting in a lower additional energy requirement and bringing greater net energy benefits.

\section{Conclusions}

As nanomaterial applications move from the laboratory to the marketplace, it will be important to consider claims of energy savings or environmental benefit against upstream manufacturing implications. This paper provides net energy results for several case studies and may provide scientists and decision makers a broad context in which to consider their research and development efforts. Many uncertainty issues exist, including CNT production scenarios, parameter uncertainties, unclear EOL impacts and possible exposure routes, and the analyses in this study show a mix of results. Although the use of CNTs to replace the graphite anode in Li-ion batteries may not be promising, SWCNT-enabled flash memory devices and MWCNT-assisted cathode in Li-ion batteries may provide promising directions as technical performance and manufacturing efficiencies increase. Advances in CNT-amended concrete may also shift the net energy benefit to be more certainly positive, however, the effect of concrete wear on the release of CNTs would need further study.

Many environmental assessments of nanomaterials focus on deleterious impacts from potential releases or only consider the high resource requirements of nanomaterial production. If all implications of nanomaterial applications were negative, there would be no reason to pursue these technologies.

Balanced assessments must also incorporate the potential energy, environmental, and health benefits of nanomaterial applications that are at the core of their development.

\section{Acknowledgements}


The authors thank S. Abbasi, A. Busnaina, C. Bosso, T. Cullinane, S. Kamarthi, L. Pourzahedi, S. Somu, and W. Walker for contributions to discussions and others at the NSF Nanoscale Science and Engineering Center for High-rate Nanomanufacturing at Northeastern University. This research was supported by a National Science Foundation Scalable Nanomanufacturing Award CMMI-1120329. 


\section{References}

1. $\quad$ lijima, S., Helical microtubules of graphitic carbon. Nature, 1991. 354(6348): p. 56-58.

2. De Volder, M.F.L., et al., Carbon Nanotubes: Present and Future Commercial Applications. Science, 2013. 339(6119): p. 535-539.

3. Park, S., M. Vosguerichian, and Z. Bao, A review of fabrication and applications of carbon nanotube film-based flexible electronics. Nanoscale, 2013. 5(5): p. 1727-1752.

4. Zhang, Q., et al., The Road for Nanomaterials Industry: A Review of Carbon Nanotube Production, Post-Treatment, and Bulk Applications for Composites and Energy Storage. Small, 2013. 9(8): p. 1237-1265.

5. Franklin, A.D., Electronics: The road to carbon nanotube transistors. Nature, 2013. 498(7455): p. 443-444.

6. Nantero 2015 [cited 2015 Aug 11]; Available from: http://nantero.com/.

7. de las Casas, C. and W. Li, A review of application of carbon nanotubes for lithium ion battery anode material. Journal of Power Sources, 2012. 208(0): p. 74-85.

8. Lo, A.-Y., et al., Study on RuO2/CMK-3/CNTs composites for high power and high energy density supercapacitor. Applied Energy, 2015. 153: p. 15-21.

9. Ghasemi, M., et al., Carbon nanotube as an alternative cathode support and catalyst for microbial fuel cells. Applied Energy, 2013. 102: p. 1050-1056.

10. The Project on Emerging Nanotechnologies--Carbon nanotube. 2015 [cited 2015 Aug 11]; Available from: http://www.nanotechproject.org/cpi/browse/nanomaterials/carbon-nanotube/.

11. ASC CNT compounds. 2015 [cited 2015 Aug 11]; Available from: http://www.ascpl.com/C16\%20Carbon\%20Nanotube\%20Compounds.html.

12. Global CNT market. 2015 [cited 2015 Aug 11]; Available from: http://www.grandviewresearch.com/press-release/carbon-nanotubes-market.

13. Kozarsky, R. Searching for profits at the intersection of nanotech and electronics. 2014 [cited 2015 Aug 11]; Available from: Lux research presentation.

14. Mauter, M.S. and M. Elimelech, Environmental Applications of Carbon-Based Nanomaterials. Environmental Science \& Technology, 2008. 42(16): p. 5843-5859.

15. Gilbertson, L.M., et al., Life Cycle Impacts and Benefits of a Carbon Nanotube-Enabled Chemical Gas Sensor. Environmental Science \& Technology, 2014. 48(19): p. 11360-11368.

16. Upadhyayula, V.K., et al., Application of carbon nanotube technology for removal of contaminants in drinking water: a review. Science of the total environment, 2009. 408(1): p. $1-$ 13.

17. Plata, D.L., et al., Early Evaluation of Potential Environmental Impacts of Carbon Nanotube Synthesis by Chemical Vapor Deposition. Environmental Science \& Technology, 2009. 43(21): p. 8367-8373.

18. Lam, C.W., et al., A Review of Carbon Nanotube Toxicity and Assessment of Potential Occupational and Environmental Health Risks. Critical Reviews in Toxicology, 2006. 36(3): p. 189217.

19. Helland, A., et al., Reviewing the Environmental and Human Health Knowledge Base of Carbon Nanotubes. Environmental Health Perspectives, 2007. 115(8): p. 1125-1131.

20. National Institute of Occupational Safety and Health, Department of Health and Human Services, Current Intelligence Bulletin 65: Occupational Exposure to Carbon Nanotubes and Nanofibers, No. 2013-145. 2013.

21. Eckelman, M.J., J.B. Zimmerman, and P.T. Anastas, Toward Green Nano: E-factor analysis of several nanomaterial syntheses. Journal of Industrial Ecology, 2008. 12(3): p. 316-328. 
22. Eckelman, M.J., et al., New perspectives on nanomaterial aquatic ecotoxicity: production impacts exceed direct exposure impacts for carbon nanotoubes. Environmental science \& technology, 2012. 46(5): p. 2902-2910.

23. Hischier, R. and T. Walser, Life cycle assessment of engineered nanomaterials: State of the art and strategies to overcome existing gaps. Science of The Total Environment, 2012. 425(0): p. 271-282.

24. Khanna, V. and B.R. Bakshi, Carbon Nanofiber Polymer Composites: Evaluation of Life Cycle Energy Use. Environmental Science \& Technology, 2009. 43(6): p. 2078-2084.

25. Healy, M.L., L.J. Dahlben, and J.A. Isaacs, Environmental Assessment of Single-Walled Carbon Nanotube Processes. Journal of Industrial Ecology, 2008. 12(3): p. 376-393.

26. Kushnir, D. and B.A. Sandén, Energy Requirements of Carbon Nanoparticle Production. Journal of Industrial Ecology, 2008. 12(3): p. 360-375.

27. Gavankar, S., S. Suh, and A.A. Keller, The Role of Scale and Technology Maturity in Life Cycle Assessment of Emerging Technologies. Journal of Industrial Ecology, 2014: p. n/a-n/a.

28. Kim, H.C. and V. Fthenakis, Life Cycle Energy and Climate Change Implications of Nanotechnologies. Journal of Industrial Ecology, 2013. 17(4): p. 528-541.

29. Wender, B.A. and T.P. Seager, Towards prospective life cycle assessment: Single wall carbon nanotubes for lithium-ion batteries, in Sustainable Systems and Technology (ISSST), 2011 IEEE International Symposium on. 2011. p. 1-4.

30. United States Environmental Protection Agency, Application of life cycle assessment to nanoscale technology: Lithium-ion batteries for electric vehicles. 2013.

31. Boustead, I. and G.F. Hancock, Handbook of industrial energy analysis. 1979: John Wiley \& Sons.

32. Brown, H.L., B.B. Hamel, and B.A. Hedman, Energy analysis of 108 industrial processes. 1996: The Fairmont Press Inc.

33. Spreng, D.T., Net-energy analysis and the energy requirement of energy systems. 1988: Praeger.

34. Carbajales-Dale, M., et al., A better currency for investing in a sustainable future. Nature Clim. Change, 2014. 4(7): p. 524-527.

35. Pellow, M.A., et al., Hydrogen or batteries for grid storage? A net energy analysis. Energy \& Environmental Science, 2015.

36. Zhai, P., et al., Net primary energy balance of a solar-driven photoelectrochemical water-splitting device. Energy \& Environmental Science, 2013. 6(8): p. 2380-2389.

37. Colclough, S. and T. McGrath, Net energy analysis of a solar combi system with Seasonal Thermal Energy Store. Applied Energy, 2015. 147: p. 611-616.

38. Razon, L.F. and R.R. Tan, Net energy analysis of the production of biodiesel and biogas from the microalgae: Haematococcus pluvialis and Nannochloropsis. Applied Energy, 2011. 88(10): p. 3507-3514.

39. Tredici, M.R., et al., Energy balance of algal biomass production in a 1-ha "Green Wall Panel" plant: How to produce algal biomass in a closed reactor achieving a high Net Energy Ratio. Applied Energy, 2015. 154: p. 1103-1111.

40. Saga, K., et al., Net energy analysis of bioethanol production system from high-yield rice plant in Japan. Applied Energy, 2010. 87(7): p. 2164-2168.

41. Khanna, V., B.R. Bakshi, and L.J. Lee, Carbon Nanofiber Production. Journal of Industrial Ecology, 2008. 12(3): p. 394-410.

42. Huijbregts, M.A., et al., Cumulative energy demand as predictor for the environmental burden of commodity production. Environmental science \& technology, 2010. 44(6): p. 2189-2196.

43. ecoinvent V2.2, Swiss Center for Life Cycle Inventories. 2013, Zurich, Switzerland.

44. Landi, B.J., et al., Carbon nanotubes for lithium ion batteries. Energy \& Environmental Science, 2009. 2(6): p. 638-654. 
45. Royal Society of Chemistry, Manufacturing the carbon nanotube market, in Chemistry World. 2007.

46. Wang, Y., et al., The large-scale production of carbon nanotubes in a nano-agglomerate fluidized-bed reactor. Chemical Physics Letters, 2002. 364(5-6): p. 568-572.

47. Li, Y., et al., Mass production of high-quality multi-walled carbon nanotube bundles on a $\mathrm{Ni} / \mathrm{Mo} / \mathrm{MgO}$ catalyst. Carbon, 2005. 43(2): p. 295-301.

48. Parveen, S., S. Rana, and R. Fangueiro, A Review on Nanomaterial Dispersion, Microstructure, and Mechanical Properties of Carbon Nanotube and Nanofiber Reinforced Cementitious Composites. Journal of Nanomaterials, 2013. 2013(710175): p. 19.

49. Abu Al-Rub, R.K., A.I. Ashour, and B.M. Tyson, On the aspect ratio effect of multi-walled carbon nanotube reinforcements on the mechanical properties of cementitious nanocomposites. Construction and Building Materials, 2012. 35(0): p. 647-655.

50. Callister, W.D., Materials Science and Engineering: An Introduction. 6th ed. 2003: John Wiley \& Sons, Inc.

51. Luo, J., Z. Duan, and H. Li, The influence of surfactants on the processing of multi-walled carbon nanotubes in reinforced cement matrix composites. physica status solidi (a), 2009. 206(12): p. 2783-2790.

52. Somu, S., et al., Bistable nanoswitch. 2011. US Patent 8,031,514 B2.

53. Dahlben, L.J., et al., Environmental Life Cycle Assessment of a Carbon Nanotube-Enabled Semiconductor Device. Environmental Science \& Technology, 2013. 47(15): p. 8471-8478.

54. Dahlben, L.J., Investigation of the environmental implications of the CNT switch through its life cycle, in Department of Mechanical and Industrial Engineering. 2010, Northeastern University.

55. Boyd, S., A. Horvath, and D. Dornfeld, Life-Cycle Assessment of NAND Flash Memory. Semiconductor Manufacturing, IEEE Transactions on, 2011. 24(1): p. 117-124.

56. Wu, Y., et al., Applications of carbon nanotubes in high performance lithium ion batteries. Frontiers of Physics, 2014. 9(3): p. 351-369.

57. Liu, X.-M., et al., Carbon nanotube (CNT)-based composites as electrode material for rechargeable Li-ion batteries: A review. Composites Science and Technology, 2012. 72(2): p. 121144.

58. Varzi, A., et al., Study of multi-walled carbon nanotubes for lithium-ion battery electrodes. Journal of Power Sources, 2011. 196(6): p. 3303-3309.

59. Luo, S., et al., Binder-Free LiCoO2/Carbon Nanotube Cathodes for High-Performance Lithium Ion Batteries. Advanced Materials, 2012. 24(17): p. 2294-2298.

60. USDOE Argonne National Laboratory. BatPac v2.2. 2011 [cited 2015 Feb]; Available from: http://www.cse.anl.gov/batpac/.

61. Types of Li-ion batteries. [cited 2015 Aug 11]; Available from: http://batteryuniversity.com/learn/article/types of lithium ion.

62. Shah, A., et al., A Layered Carbon Nanotube Architecture for High Power Lithium Ion Batteries. Journal of The Electrochemical Society, 2014. 161(6): p. A989-A995.

63. van Vliet, O., et al., Energy use, cost and CO2 emissions of electric cars. Journal of Power Sources, 2011. 196(4): p. 2298-2310.

64. Nissan LEAF. [cited 2015 Aug 11]; Available from: http://www.nissanusa.com/electriccars/leaf/charging-range/battery/.

65. Finnveden, G., et al., Recent developments in Life Cycle Assessment. Journal of Environmental Management, 2009. 91(1): p. 1-21.

66. Hauck, M., et al., How to quantify uncertainty and variability in life cycle assessment: the case of greenhouse gas emissions of gas power generation in the US. Environmental Research Letters, 2014. 9(7): p. 074005. 
67. Arvidsson, R., et al., Energy and resource use assessment of graphene as a substitute for indium tin oxide in transparent electrodes. Journal of Cleaner Production, doi:10.1016/j.jclepro.2015.04.076.

68. Goriparti, S., et al., Review on recent progress of nanostructured anode materials for Li-ion batteries. Journal of Power Sources, 2014. 257(0): p. 421-443.

69. Li, B., et al., Life Cycle Environmental Impact of High-Capacity Lithium Ion Battery with Silicon Nanowires Anode for Electric Vehicles. Environmental Science \& Technology, 2014. 48(5): p. 3047-3055.

70. Wang, W., et al., Hybrid carbon nanotube and graphene nanostructures for lithium ion battery anodes. Nano Energy, 2014. 3(0): p. 113-118.

71. Lithium-ion batteries for electric vehicles: th US value chain. 2010, Center on Globalization Governance and Competitiveness

72. Greenhouse Gas Equivalences Calculator. 2015, US Environmental Protection Agency.

73. Consumer Product Safety Commission and the National Nanotechnology Initiative, Quantifying Exposure to Engineered Nanomaterials (QEEN) from Manufactured Products: Addressing Environmental, Health, and Safety Implications, Workshop held July 7-8, 2015.

74. Köhler, A.R., et al., Studying the potential release of carbon nanotubes throughout the application life cycle. Journal of Cleaner Production, 2008. 16(8-9): p. 927-937.

75. Wang, Y., et al., Microstructure and thermal characteristic of Si-coated multi-walled carbon nanotubes. Nanotechnology, 2006. 17(15): p. 3817.

76. Yang, S., et al., Thermal analysis of an acrylonitrile-butadiene-styrene/SWNT composite. Polymer degradation and stability, 2004. 83(3): p. 383-388. 


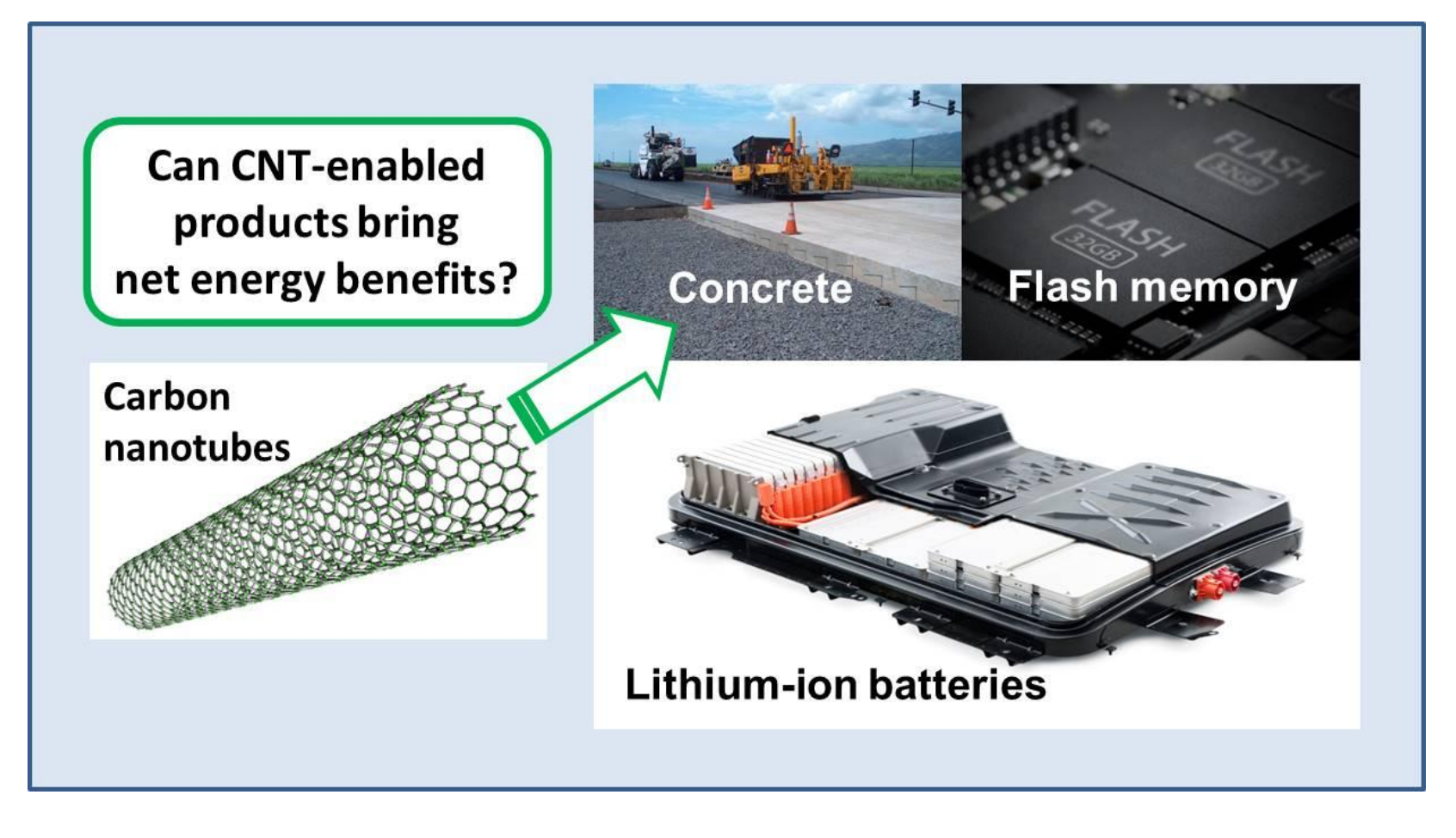

